\title{
Building Trust: A Solution to Increase User's Satisfaction on E-Money Adoption
}

\author{
Meuthia \\ Management Department, Andalas University \\ Padang, Indonesia \\ E-mail: meuthia.ute@gmail.com
}

\begin{abstract}
The main impetus of this study is to test empirically the antecedents of users' satisfaction on e-money adoption. Trust has been considered as a major concern for this study, which then stimulates system quality and user's participation. This study uses quantitative approach through an online survey of 117 e-money users in Indonesia. The tool of analysis is Structural Equation Modeling (SEM) with Partial Least Square (PLS) software. The result of this study revealed that high level of trust when followed by system quality and participation being a stimulant for higher level of users' satisfaction.
\end{abstract}

Keywords: E-money, trust, system quality, participation, users’ satisfaction, PLS.

\section{Introduction}

Adoption of e-money in Indonesia is growing well. The use of e-money transactions has increased from IDR 5 billion in 2007 to IDR 30 trillion. Nowadays, approximately USD 7.7 billion rotates each day using emoney services such as e-wallet and prepaid cards in Indonesia $^{1 .}$

Bank of Indonesia defines electronic money as any kind of money stored in a system such as a server or chip. The object is used by the consumer as an e-wallet service or pre-paid card. Both are very useful in countries that have a very low credit card penetration, because it helps the community to make online payments or save money for purposes such as paying a bus ticket or bill.

Most of banks in Indonesia have e-money products in the form of a prepaid card. This card can be used by anyone, and the bank usually cooperates with universities to integrate identity card of students into a prepaid card. These cards usually can store a maximum of 1 million rupiahs. With five million cards have been issued, Flazz is a leader and multifunctional prepaid cards from Bank Central Asia. Purchases and payment which can be done in second at more than 23,000 outlets available, then promo as diverse as free parking for the first hour in some places become advantages.
These advantages supported by state of the art technology such as: chip and Radio Frequency Identification (RFID). Hence, this study focused on Flazz as e-money product observed.

Given the fact that adoption rates of e-money in Indonesia have been increased significantly and their potential advantages for users, there is a strong need for examining the factors that influence users adoption. Few studies explored the adoption of e-money ${ }^{2,3,4,5}$. As a part of new e-business product, trust has been considered as a major concern for this study, which then stimulates system quality and user's participation to adopt this product.

Diversity of studies through the domains that describe the dimensions and the debate about concept of trust have indicated the need for more specific analysis of the linkage between trust and satisfaction as the outcome of those trust's constructs ${ }^{6,7}$.

The purposes of this study are congruent with the research questions that may be proposed from the model of linkage between trust and users' satisfaction, which are investigate:

- The effect of trust on system quality,

- The effect of trust on participation,

- The effect of participation on satisfaction, and

- The effect of system quality on satisfaction. 
This paper is organized as follows. In the beginning, it presents the relevant bacground. It follows by the linkage of each variables to propose the hypothesis development. Then, it continued by research method and results to answer the research questions. In the last section, the conclusion and implication are discussed.

\section{Background}

This paper is motivated by empirical studies on trust which are still divergent. Divergent related to belief as a broad concept, because it covered variety of relationships in any aspect of human's life ${ }^{8}$. This view has later been studied from psychology, because it related to a person's attitude 9 . This study then led to the diversity of the trust's dimensions. This paper uses the most widely accepted views, which are dimension of credibility and benevolence ${ }^{10,11,12,13}$.

Credibility refers to competency, honesty, and seller's reliability ${ }^{14}$; benevolence refers to seriousness of the seller's willingness to consider the welfare of buyers ${ }^{15}$. In this paper, trust as the function of credibility and benevolence dimensions is accordance with the opinion of Dimoka ${ }^{16}$. Dimoka's research used as reference because the model of this research was created by the perspective that construct of user's satisfaction is the function of trust in individual decision for using product or service which is also influenced by another constructs (system quality and users' participation), which was built through cognitive process and emotional from the trust.

This study discusses about the role of trust which has been widely accepted by information system's researchers, but there were still few people who did the study about distrust ${ }^{17}$. The scarcity of distrust's research comes from previous research that makes trust and distrust as the same construct at the opposite ends of a single continuum ${ }^{16,18}$.

Contrary to the researcher who view trust and distrust as the same construct in the opposite ends, then some other researchers actually see trust and distrust appear simultaneously ${ }^{19}$. Empirical researches that state trust and distrust appear simultaneously are based on two distinct constructs and its correlation is low ${ }^{20}$.

This paper refers to the perspectives of trust and distrust as distinct constructs, referred to the association with brain activity system's theory by Dimoka ${ }^{16}$ and the theory of Lewicki et $\mathrm{al}^{19}$. E-money card is used in this paper as one of the instrument on e-money context that exemplifies the process of trust based on the argument that congruent to Dimoka's research and theory of Lewicki et al.

\section{Theoretical Framework and Hypothesis Development}

Numerous empirical studies about trust, but rarely have they investigate trust as an antecedents of users satisfaction on e-money adoption. Some studies explored trust in technology as an important factor in the context of e-government and internet banking ${ }^{21}$, but few studies considered trust as antecedent in egovernment $\mathrm{t}^{22,23}$, trust as antecedent to customer satisfaction $^{24}$, trust as antecedent in online tax-filling system which in turn directly influenced all three IS Quality dimensions ${ }^{25}$, trust as antecedent to the attitude and intention to use mobile payment $\mathrm{t}^{26,27,28,29}$. Basically, trust can be divided into two types: trust in the entity providing the service and trust in technology $\mathrm{y}^{22,23,30,31,32,33,34,25}$.

\subsection{The effect of trust on system quality and participation}

Relationship between user trust and electronic quality's attribute generally explained through attribution theory that shows the perception and allegation which arise when people try to explain the others or their self actions ${ }^{23,35,24}$. The trust of user toward vendor, merchant, and technology that are provided by vendor have been affected the valuation toward system quality from users. Trust toward electronic vendor involves trust that vendor will be responsible for guarantee the technical liability and the ease of use from e-money product, then encourage high quality perception of the e-money product innovation system.

User who trusts in merchant that manage vendor product will be able to face technical issues effectively to increase product usability. When users do not trust that they will get the certainty about detail of technical feature and various standard points from e-money product, they will show their dissatisfaction on product.

The trust of users decrease when they feel unsafe in using system and didn't find the practically and efficiency of this system, so that they will perceive that service which is given by the card is poor and cause dissatisfaction in using $\mathrm{it}^{36}$. Associated with activity in brain system, trust toward system quality was driven by different neurological process in the prefrontal cortex, especially orbitofrontal cortex. Orbitofrontal cortex will stimulate cognitive process in human that related to perception or individual assessment in explaining things.

According to social exchange theory, people form a relationship of exchange with basic of trust ${ }^{37}$. User participation also being a consequence of trust despite of system quality. User participation in system 
development has already understood as critical factor in achieving success of information system ${ }^{38}$.

User participation is a behavior, assessments, and activities performed by users or their representatives during the process of system development ${ }^{39}$. The lack of trust will preclude participation in the use of e-money product because the uncertainty that contained from use of the product. Trust is the first condition for user's participation in e-money.

Participation of user in internet banking is measured with presence of community involvement in the use of certain product to do interaction and transaction ${ }^{40}$. User participation will grow well if product service can support the trust that is given by user ${ }^{37}$. Jung-Yu et al. ${ }^{41}$ also has investigated that trust and user participation being a significant driver of e-business satisfaction. Five cluster of IT features, which consist of usability, transparency, quality-assured content, security, and privacy has different impact on trust and participation ${ }^{42}$.

If user participation associated with brain activity system $^{16}$, the benevolence dimension based on brain activity (neural) associated with limbic system. Limbic system is generally associated with social and emotional processes that activate interior area of brain (likes amygdala, caudate nucleus, putamen, and insular cortex) to encourage the rising of hope, reward, positive respond, and willing to cooperate or participate. Credibility dimension based on brain activity associated with prefrontal cortex also affect the user participation through a decision to declare the use of system is satisfy them. Therefore, it encourages them to participate using a product. Based on a review of the literature, the author develops these following hypotheses:

H1a: Trust has positive influence on system quality

$\mathrm{H} 1 \mathrm{~b}$ : Trust has positive influence on participation.

\subsection{The effect of system quality and participation on satisfaction}

Study which is conducted by $\mathrm{Teo}^{23}$ found that system quality affect satisfaction which in turn affects the interest to continue for using e-government. System quality indicates perception about technical performance in obtaining and sending information. Prior research by Petter et al. ${ }^{43}$ identified 43 determinants that provided influence the IS success. Subsequently, they examined which determinants affect the dimensions of IS success - system quality, information quality, service quality, intention to use, system use, user satisfaction, and net benefits.

Technically, product should provide easy access and timely to serve reliable information and protect function or ensure the safety of users when doing transaction in online banking website ${ }^{44}$. Clear information, up to-date, accurate, correct, served by system that can be operated easily, no-trouble, friendly service and fast both by vendor and merchant, encourage users to give high rating about product quality, which in turn leads to satisfaction toward product ${ }^{45,46,47,48,49}$.

Users' trust in influencing satisfaction relates not only to website's attributes likes system quality, but also users' participation. The extent to which users' participation will certainly affect satisfaction with the system. McKeen et al. ${ }^{50}$ found that users' participation in the system development directly affects users' satisfaction and system usage. Users' participation in system development should lead to greater commitment, involvement, acceptance, usage, and ultimately gain greater satisfaction ${ }^{51,52,53,54}$. Based on those literature reviews, the author develops these following hypotheses:

H2a: System quality has positive influence on satisfaction

$\mathrm{H} 2 \mathrm{~b}$ : Participation has positive influence on satisfaction

The linkages among variables within hypothesis development are depicted in proposed research model as figure 1 below:

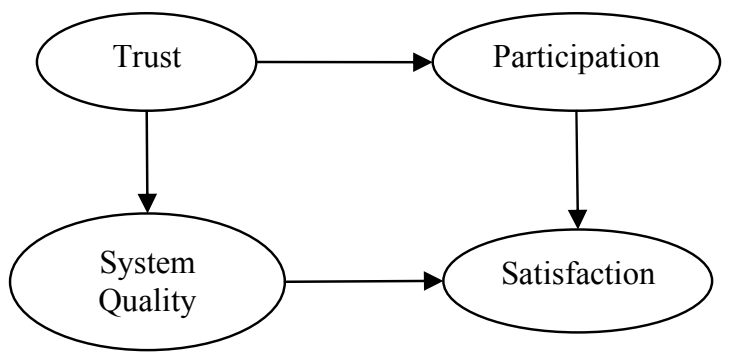

Fig 1. Research Proposed Model

\section{Research Method}

Quantitative research design had been selected in order to find out the appropriate answers to the research questions and to test the hypotheses. Survey method was used to collect data through distributing questionnaires. The distribution is done through online survey by using free online surveys, (kwiksurveys and my3q link).

The population which is chosen to be the object of this research is that users of e-money product in Indonesia. Sample selection is done by using purposive sampling method, because individual samples are only the users who had used the Flazz card for making transaction at all merchants over Indonesia.

The number of respondents whose have contacted as many as 371 respondents to anticipate the questionnaires which are not returned. The numbers of respondents and questionnaires that can be analyzed are 
117 respondents. This research uses analysis tool of Structural Equation Modeling (SEM) with Partial Least Square software.

\section{Results}

\subsection{Outer Model: Validity and Reliability Testing}

The measurement model of indicator on reflective construct had been examined by testing: (1) construct validity (with convergent validity and discriminant validity), and (2) internal consistency (reliability measurement with composite reliability). To examine the measurement model of indicator on reflective construct is done by algorithm process through outer loading value. The output of initial outer model can be seen in table 1 below.

Table 1. Initial Outer Model (Convergent Validity, Discriminant Validity and Reliability)

\begin{tabular}{|c|c|c|c|c|c|c|}
\hline Indicators & PARTICIPATION & SATISFACTION & SYSTEM QUAL & TRUST & AVE & $\begin{array}{l}\text { COMPOSITE } \\
\text { RELIABILITY }\end{array}$ \\
\hline $\mathrm{KC} 1$ & 0,308949 & 0,276811 & 0,351002 & 0,627204 & & \\
\hline $\mathrm{KC} 2$ & 0,455000 & 0,421067 & 0,514727 & 0,787853 & & \\
\hline $\mathrm{KC} 3$ & 0,105118 & 0,336615 & 0,443911 & 0,739275 & 0,511149 & 0,838254 \\
\hline $\mathrm{KC} 4$ & 0,239671 & 0,519003 & 0,523647 & 0,767175 & & \\
\hline $\mathrm{KC5}$ & 0,274186 & 0,264924 & 0,396160 & 0,637623 & & \\
\hline KP1 & 0,290130 & 0,645712 & 0,420863 & 0,342231 & & \\
\hline KP2 & 0,301898 & 0,688246 & 0,404262 & 0,371757 & & \\
\hline KP3 & 0,351886 & 0,793392 & 0,463586 & 0,438531 & 0,415227 & 0,826339 \\
\hline KP4 & 0,206634 & 0,740163 & 0,447640 & 0,352221 & & \\
\hline KP5 & 0,226701 & 0,671594 & 0,319963 & 0,262951 & & \\
\hline KP6 & 0,253895 & 0,489323 & 0,284041 & 0,303860 & & \\
\hline KP7 & 0,059283 & 0,384937 & 0,172780 & 0,240042 & & \\
\hline $\mathrm{KS} 1$ & 0,307952 & 0,357138 & 0,657166 & 0,448559 & & \\
\hline $\mathrm{KS} 2$ & 0,139622 & 0,304940 & 0,743459 & 0,520984 & & \\
\hline KS3 & 0,196324 & 0,427579 & 0,798482 & 0,466637 & 0,527876 & 0,847510 \\
\hline KS4 & 0,197078 & 0,553796 & 0,760019 & 0,499024 & & \\
\hline KS5 & 0,333671 & 0,435355 & 0,663007 & 0,346429 & & \\
\hline PS1 & 0,761264 & 0,282862 & 0,134365 & 0,295150 & & \\
\hline PS2 & 0,742782 & 0,197933 & 0,160571 & 0,195163 & & \\
\hline PS3 & 0,716161 & 0,176235 & 0,180634 & 0,223677 & 0,547977 & 0,857079 \\
\hline PS4 & 0,849045 & 0,359582 & 0,354203 & 0,389512 & & \\
\hline PS5 & 0,612267 & 0,354448 & 0,262889 & 0,312331 & & \\
\hline
\end{tabular}

Source: Support Data PLS (2014)

The indicators will be stated as valid if the value of outer loading more than 0.70 . but, for loading $0.50-0.70$ still can be accepted as long as the value of AVE and communality more than $0.50^{55} .22$ initial indicators had been proposed, but not all of them meet the rule of thumb for measurement indicator model.
Two indicators of satisfaction are being dropped, because their loading value and AVE show below 0,5. Then, the author re-run 20 indicators remaining. Table 2 shows outer model revision after two indicators (KP6 and KP7) had been deleted.

Table 2. Outer Model Revision (Convergent Validity, Discriminant Validity and Reliability)

\begin{tabular}{cccccc}
\hline Indicators & PARTICIPATION & SATISFACTION & SYSTEM QUAL & TRUST & AVE \\
\hline KC1 & 0,309184 & 0,249359 & 0,351132 & 0,627135 & COMPOSITE \\
RC2 & 0,455298 & 0,424254 & 0,514755 & 0,787744 & 0,511161 \\
KC3 & 0,105234 & 0,285912 & 0,444522 & 0,739372 & 0,838259 \\
KC4 & 0,240514 & 0,492507 & 0,524389 & 0,767351 & \\
KC5 & 0,274846 & 0,253938 & 0,395971 & 0,637547 & \\
\hline
\end{tabular}




\begin{tabular}{llllll}
\hline KP1 & 0,291061 & 0,708696 & 0,421128 & 0,342249 & \\
KP2 & 0,302597 & 0,730708 & 0,404398 & 0,371788 & 0,529350 \\
KP3 & 0,352344 & 0,789063 & 0,463128 & 0,438556 & 0,848529 \\
KP4 & 0,206826 & 0,749546 & 0,447731 & 0,352242 & \\
KP5 & 0,226790 & 0,652786 & 0,319469 & 0,262972 & 0,527842 \\
KS1 & 0,308150 & 0,334127 & 0,654817 & 0,448534 & \\
KS2 & 0,139255 & 0,310976 & 0,745210 & 0,520979 & 0,847453 \\
KS3 & 0,196500 & 0,418873 & 0,798849 & 0,466675 & \\
KS4 & 0,197731 & 0,554810 & 0,761485 & 0,499064 & \\
KS5 & 0,333840 & 0,419397 & 0,661111 & 0,346404 & \\
PS1 & 0,761542 & 0,277827 & 0,132847 & 0,295127 & \\
PS2 & 0,740818 & 0,181823 & 0,159746 & 0,195114 & \\
PS3 & 0,715491 & 0,166528 & 0,179443 & 0,223585 & 0,547622 \\
PS4 & 0,849295 & 0,347809 & 0,352855 & 0,389463 & 0,856910 \\
PS5 & 0,613287 & 0,346008 & 0,262607 & 0,312276 & \\
\hline Source: Supp & Data PLS(2014) & & & \\
\hline
\end{tabular}

Source: Support Data PLS (2014)

Table 2 above shows that all of the indicators meet the criteria of validity. Beside validity test, all of the indicators also should be tested by reliability test. Reliability value can be seen in table 2 above from the value of composite reliability which greater than 0,70 . Rule of thumb value for composite reliability must be greater than 0.7 , but 0.6 though still acceptable ${ }^{56}$.
The discriminant validity is not only can be tested from the loading value, but also can be seen by comparing the root of AVE (Square Root of Average) of a construct which must be higher than the correlation between latent variables. Table 3 below shows discriminant validity of this study.

\begin{tabular}{ccccc}
\multicolumn{5}{c}{ Table 3. Discriminant Validity: Latent Variable Correlations } \\
\hline & PARTICIPATION & SATISFACTION & SYSTEM QUAL & TRUST \\
\hline PARTICIPATION & 0,740015 & & & \\
SATISFACTION & 0,383578 & 0,727564 & & \\
SYSTEM QUAL & 0,315736 & 0,570070 & 0,726528 & \\
TRUST & 0,406212 & 0,492468 & 0,631959 & 0,714955 \\
\hline
\end{tabular}

Source: Support Data PLS (2014)

\section{Inner model: structural model testing}

Structural model testing includes estimating the path coefficients that identify the strengths of relationship between dependent variable and independent variable.
Structural model testing generates significant value of path relationship among latent variables by using bootsrapping function ${ }^{57}$. Table 4 below shows hypothesis testing for this study.

Table 4. Inner model (Hypothesis Testing)

\begin{tabular}{lcc}
\hline \multicolumn{1}{c}{ HYPOTHESIS } & Original Sample $(\mathrm{O})$ & T Statistics $(|\mathrm{O} / \mathrm{STERR}|)$ \\
\hline TRUST $\rightarrow$ SYSTEM QUAL & 0,631959 & $10,684574^{*}$ \\
TRUST $\rightarrow$ PARTICIPATION & 0,406212 & $6,298429^{*}$ \\
SYSTEM QUAL $\rightarrow$ SATISFACTION & 0,498673 & $7,355675^{*}$ \\
PARTICIPATION $\rightarrow$ SATISFACTION & 0,226129 & $3,043623^{*}$ \\
\hline
\end{tabular}

*) Significant at $\alpha 0,05$ (T-value greater than 1,96)

Source: Support Data PLS (2014)

The result of hypothesis 1a testing shows that trust has positive and significant influence on system quality. This is indicated by coefficient value of trust $->$ system qual is 0,631959 and $t$ value of 10,684574 . This finding answers the first research objective which examines the influence of trust on system quality. Hypothesis 1a is supported, because trust has positive influence on system quality with $95 \%$ confidence level.
The result of hypothesis $1 \mathrm{~b}$ testing shows that trust has positive influence toward user participation. It indicated by coefficient value of trust $->$ participation is 0,406212 and $t$ value of 6,298429 . This finding answers the second research objective which examines the influence of trust toward user participation. Hypothesis $1 \mathrm{~b}$ is supported, because trust has positive influence on user participation with $95 \%$ confidence level. 
The result of hypothesis $2 \mathrm{a}$ testing shows that system quality has positive influence toward user satisfaction. This is indicated by coefficient value of system qual $->$ satisfaction is 0,498673 and $t$ value of 7,355675. This finding answers the third research objective which examines the influence of system quality toward user satisfaction. Hypothesis $2 \mathrm{a}$ is supported, because system quality has positive influence on user satisfaction and significant at $95 \%$ confidence level.

The result of hypothesis $2 b$ testing shows that user participation has positive influence toward user satisfaction. This is indicated by coefficient value of participation -> satisfaction is 0,226129 and $t$ value of 3,043623 . This finding answers the fourth research objective which examines the influence of user participation toward user satisfaction. Hypothesis $2 b$ is supported, because user participation has positive influence on user satisfaction and significant at $95 \%$ confidence level.

\section{Discussion}

\subsection{Findings Related to Hypothesis 1a The effect of trust on system quality}

Human brain activity's system has linkage to the trust. Brain activity of E-money card users to believe will stimulate cognitive process through neural prefrontal cortex. Thus, it influences users' assessment toward product they used. Brain activity system's theory which is proposed then may underlie the results of hypothesis testing in contextual phenomenon.

The test results in descriptions of first hypothesis, related to the influence of trust toward information's attribute associated with e-money product's context on the smart card in Indonesia, then E-money card users' trust toward vendor, merchant, and technology that support it will encourage the users to provide good quality rating toward system quality.

\subsection{Findings Related to Hypothesis $1 \mathrm{~b}$ The effect of trust on participation}

Social exchange theory ${ }^{37}$ stated that human does an exchange relationship on the basis of trust. E-money card users who have high trust toward vendors will be willing to increase the number of transaction. This condition encourages users also be willing to do top up (recharge) for their cards in great amount even routine. When a user find a complaint in conducting transaction with E-money card, this user also will utilize Halo BCA service because this user believes that the transaction problem can be solved quickly and responded well by the officers. Users believe, BCA has provided both good knowledge and skill to the officers.

\subsection{Findings Related to Hypothesis $2 a$ \\ The effect of participation on satisfaction}

Users participation through evaluating cost efficiency and time of transaction was increased thus increasing satisfaction. This efficiency comes from the perceived ease of users toward system that makes the system considered more qualified and may increase satisfaction when using this system.

Time efficiency is obtained when users feel the speed and practicality of transaction rather than using both debit and credit cards that require the input of PIN and signature as authorization form. User perceived cost efficiency when E-money card transaction system does not burden the users with many rules in processing procedure, no tax deduction, spared from the problem of counterfeit money and fraudulent refund that are often not properly up to cost advantage of special discount from certain merchant for E-money card users.

\subsection{Findings Related to Hypothesis $\mathbf{2 b}$ The effect of system quality on satisfaction}

Users which perform an increasing number of transaction and regular top-up show that they are satisfied with E-money card caused of efficiency and ease of use offered. Related to social exchange theory, user participation is initially influenced by trust through cognitive and affective stimulant resulted in the emergence of positive decision to participate using Emoney card product. The depth of user involvement toward product reflects user satisfaction toward product. E-money card user which is increasing the number of transaction and top up caused of both discount and promo which was provided by merchant reflects user satisfaction because of the cost will be lower.

\section{Conclusion}

Evidently, trust was not a major concern in the context of smart card. Cognitive stimuli and emotional that affect human brain activity's system to have trust in the decision or give assessment of things are not entirely encouraging satisfaction on Flazz BCA card users. There are other factors that become stimulants for the fulfillment of Flazz BCA card users' satisfaction, which focus on system quality and participation of users. High level of trust when followed by system quality and 
participation was also a stimulant for being high level of users' satisfaction.

The results of this study are expected to provide the theoretical implications of the linkage between trust and satisfaction of smart card users, especially on e-money products. Participation as an additional construct which elaborated the theory of human brain activity system by Dimoka ${ }^{16}$ has contributed in shaping the perspective that the function of satisfaction is not only built by the trust, but also by association with other variables such as system quality, participation, and user participation.

Concept from Dimoka ${ }^{16}$ associated with human brain activity system refers to the perspective of trust and distrust as two distinct constructs that emerge simultaneously. Trust and distrust that has a value in a certain range will appear simultaneously as a pendulum. Low levels of trust not indicate a high level of distrust. A high or low level of trust indicates the level of system quality and user participation. The lack of accuracy in determining the point that indicates the level of trust and distrust will affect the level of user satisfaction. Thus, accuracy in assessing the level of trust becomes important in the level of user satisfaction.

The results of this study in addition to providing theoretical implications are also expected to provide practical implications. Practically, when dealing with the positive response, trust on merchant (bank) can be increased through management system and good information about the utilization of Flazz. Bank need to improve the system reports the remaining balance which is often not accurate to use a more accurate system for detecting miscalculation when making a transaction.

The quality system also needs to be improved related to the policy of innovation technology systems that are used in order to offer the ease of use and practicality of the product. Bank also need to provide reports and information that is precise, correct, clear, and the latest on the merchant's promos and discounts that attract users to top up which in turn increases the number of transactions. Negative effect on the quality of service user satisfaction can also be a reference for vendors to improve the performance of personnel providing services. Bank need to improve skills through training, reward those who perform good service to users, and the provision of punishment for officials who tend to neglect in response to user complaints. Generally, the results of this study are expected to provide input for the banking sector as a provider of emoney products in predicting the level of user satisfaction.

APPENDIX

\begin{tabular}{|c|c|c|}
\hline Variables & Indicators & References \\
\hline \multirow{7}{*}{ Trust } & $\mathrm{KC} 1=$ Security & \multirow{6}{*}{$23,58,59,60$} \\
\hline & $\mathrm{KC} 2=$ Relevancy & \\
\hline & KC3 = Overall Eficiency & \\
\hline & KC4 = Problem Solving & \\
\hline & KC5 = Ability & \\
\hline & $\mathrm{KP} 1=$ Incentives & \\
\hline & $\mathrm{KP} 2=$ Requirements & \multirow{6}{*}{$23,61,62,63$} \\
\hline \multirow[t]{7}{*}{ Satisfaction } & KP3 = Inventory Efficiency & \\
\hline & KP4 = Time Efficiency & \\
\hline & KP5 = Cost Efficiency & \\
\hline & *KP6 = Certainty & \\
\hline & $* \mathrm{KP} 7=$ Accuracy & \\
\hline & $\mathrm{KS} 1=$ Operational problem & \multirow{5}{*}{$64,65,66,67,68$} \\
\hline & $\mathrm{KS} 2=$ Procedural time efficiency & \\
\hline \multirow[t]{5}{*}{ System Quality } & KS3 = Quick verification & \\
\hline & KS4 $=$ Practicability & \\
\hline & KS5 $=$ Ease of use & \\
\hline & PS1 = Quality & \\
\hline & PS2 = Quantity & \multirow{4}{*}{$37,51,69,70$} \\
\hline \multirow{3}{*}{ Participation } & PS3 = Complaint & \\
\hline & PS4 = Recommendation & \\
\hline & PS5 $=$ Supporting involvement & \\
\hline
\end{tabular}

*) KP6 and KP7 has been deleted on bootsrapping process

Source: Previous Studies 


\section{REFERENCES}

1. E. Lukman, 17 Pemain E-Money Indonesia yang bisa Anda Gunakan untuk Belanja, Tech in Asia (June 27, 2014).

2. M. Andrieu, The Future of E-Money: Main Trends and Driving Forces, Foresight. 3(5) (2001) 429 - 451.

3. M. Baddeley, Using E-Cash in the New Economy: An Economic Analysis of Micropayments Systems, Journal of Electronic Commerce Research. 5(4) (2004) 239-253.

4. H. Roberts, \& S. Gregor, Why Australian Merchants aren't Adopting E-money?, Journal of Research and Practice in Information Technology. 37(1) (2005) 11-25.

5. E. Micheni, I. Lule, \& G. M. Muketha, Transaction Costs and Facilitating Conditions as Indicators of the Adoption of Mobile Money Services in Kenya, International Journal of Advanced Trends in Computer Science and Engineering, 2(5) (2013) 09-15.

6. D. Gefen, E. Karahanna, \& D. W. Straub, Trust and TAM in Online Shopping, MIS Quarterly, 27(1) (2003) 51-90.

7. D. Gefen, \& D. W. Straub, Consumer Trust in B2C ECommerce and the Importance of Social Presence: Experiments in E-Products and E-Services, The International Journal of Management Science, 32 (2004) 407-424.

8. S. E. Colesca, Increasing E-Trust: A Solution to Minimize Risk in E-Government Adoption, Journal of Applied Quantitative Methods, 4(1) (2009) 31-44.

9. R. Bachmann, \& A. Zaher, Handbook of Trust Research. (Massachussets: Edward Elgar Publishing, 2008).

10. R. C. Mayer, F. D. Schoorman, \& J. H. Davis, An Integrative Model of Organizational Trust, Academy of Management Review. 20(3) (1995) 709-734.

11. S. Ba, \& P. A. Pavlou, Evidence of The Effect of Trust in Electronic Markets: Price Premiums and Buyer Behavior, MIS Quarterly, 26(3) (2002) 243-267.

12. P. M. Doney, \& J. P. Cannon, An Examination of the Nature of Trust in Buyer-Seller Relationships, Journal of Marketing, 61(1) (1997) 35-51.

13. J. Singh, \& D. Sirdeshmukh, Agency and Trust Mechanisms in Consumer Satisfaction and Loyalty Judgments, Journal of the Academy of Marketing Science, 28(1) (2000) 150-167.

14. D. Sirdeshmukh, J. Singh, \& B. Sabol, Consumer Trust, Value, and Loyalty in Relational Exchanges, Journal of Marketing, 66(1) (2002) 367-392.

15. E. Garbarino, \& O. F. Lee, Dynamic Pricing in Internet Retail: Effects on Consumer Trust, Psychology \& Marketing, 20(6) (2003) 495-513.

16. A. Dimoka, What Does the Brain Tell Us about Trust and Distrust? Evidence from A Functional Neuroimaging Study, MIS Quarterly, 34(2) (2010) 373-396.

17. D. H. McKnight, \& N. L. Chervany, While Trust is Cool and Collected, Distrust is Fiery and Frenzied: A Model of Distrust Concepts, in Proceedings of the 6th Americas Conference on Information Systems, M. Chung (ed.), Long Beach, CA, August 10-13 (2000) 883-888.

18. J. Benamati, M. A. Serva, \& M. A. Fuller, Are Trust and Distrust Distinct Constructs? An Empirical Study of the
Effects of Trust and Distrust among Online Banking Users, in Proceedings of the 39th Hawaii International Conference on System Sciences (Los Alamitos, CA: IEEE Computer Society Press, 2008).

19. B. J. Lewicki, D. J. McAllister, \& R. J. Bies, Trust and Distrust: New Relationships and Realities, Academy of Management Review, 23(3) (1998) 438-458.

20. D. H. McKnight, \& V. Choudhury, Distrust and Trust in B2C E-Commerce: Do They Differ?, in Proceedings of the 2006 International Conference on Electronic Commerce, (Fredericton, New Brunswick, Canada. August, 2006), pp. 14-16.

21. A. L. Zhao, N. K. Lewis, S. H. Llyord, P. Ward, P, Adoption of Internet Banking Services in China: Is it All about Trust?, International Journal of Bank Marketing. 28(1) (2010) 7-26.

22. F. Belanger, \& L. Carter, Trust and Risk in E-Government Adoption, Journal of strategic Information Systems, 17(2) (2008) $165-176$.

23. T. S. H. Teo, S. C. Srivastava, \& L. Jiang, Trust and Electronic Government Success: An Empirical Study, Journal of Management Information Systems, 25(3) (2009) 99-131.

24. F. Liébana-Cabanillas, M. Martínez-Fiestas, F. RejónGuardia, \& F. Muñoz-Leiva, Gender as a Moderating Element of Customer Satisfaction with Electronic Banking? An Empirical Study, The International Journal of Management Science and Information Technology, 5 (2012): 1-33.

25. J. V. Chen, R. J. Jubilado, E. P. S. Capistrano, \& D. C. Yen, D. C, Factors Affecting Online Tax-Filling - An Applcation of the IS Success Model and Trust Theory, Computers in Human Behavior. 43 (2015) 251-262.

26. D. H. Shin, Towards an Understanding of the Consumer Acceptance of Mobile Wallet, Computers in Human Behavior. 25 (2009) 1343-1354.

27. S. Chandra, S. C. Srivastava, \& Y. L. Theng, Evaluating the Role of Trust in Consumer Adoption of Mobile Payment Systems: An Empirical Analysis. Communications of the Association for Information Systems, 27 (2010) 561-588.

28. S. Yang, Y. Lu, S. Gupta, Y. Caso, \& R. Zhang, Mobile Payment Services Adoption Across Time: An Empirical Study of the Effects of Behavioral Beliefs, Social Influences, and Personal Traits. Computers in Human Behavior, 28 (2012) 129-142.

29. F. Liébana-Cabanillas, J. Sanchez-Fernandes, \& F. Munoz-Leiva, Antecedents of the Adoption of the New Mobile Payment Systems: The Moderating Effect of Age, Computers in Human Behavior. 35 (2014) 464-478.

30. S. C. Srivastava, \& T. S. H. Teo, Citizen Trust Development for E-Government Adoption and Usage: Insights from Young Adults in Singapore, Communacations of the Association for Information Systems. 25(31) (2009) 359-378.

31. J. Lee, H. J. Kim, \& M. J. Ahn, The Willingness of EGovernment Service Adoption by Business Users: The Role of Offline Service Quality and Trust in Technology, Government Information Quarterly. 28(2) (2011) 222-230. 
32. A. Beldad, M. D. Jong, \& M. Steehouder, I Trust not Therefore It Must be Risky: Determinants of the Perceived Risks of Disclosing Personal Data for E-Government Transactions, Computers in Human Behavior. 27(6) (2011) 2233-2242.

33. A. Beldad, T. V. D. Geest, M. D. Jong, \& M. Steehouder, A Cue or Two and I'll Trust You: Determinants of Trust in Government Oragnizations in Terms of Their Processing and Usage of Citizens' Personal Information Disclosed Online, Government Information Quarterly. 29(1) (2012) 41-49.

34. V. Weerakkody, R. El-Haddadeh, F. Al-Sobhi, M. A. Shareef, \& Y. K. Dwivedi, Examining the Influence of Intermediaries in Facilitating E-Government Adoption: An Empirical Investigation, International Journal of Information Management. 33(5) (2013) 716-725.

35. D. H. McKnight, V. Choudhury, \& C. Kacmar, Developing and Validating Trust Measures for ECommerce: An Integrative Typology, Information Systems Research. 13(3) (2002) 334-359.

36. R. J. Sullivan, Can Smart Card Reduce Payment Fraud and Identity Theft?, Economic Review, 93(3) (2008) 35-62.

37. L. Tung, P. Tan, P. Chia, Y. Koh, \& H. L. Yeo, An Empirical Investigation of Virtual Communities and Trust, Proceedings of the International Conference on Information Systems, 2001, 307-320.

38. E. B. Swanson, Management Information Systems: Appreciation and Involvement", Management Science, 21(2) (1974) 178-188.

39. H. Barki, \& J. Hartwick, Rethinking the Concept of User Involvement, MIS Quarterly, 13(1) (1989) 53-64.

40. S. G. Krauter, R. Faullant, Consumer Acceptance of Internet Banking: The Influence of Internet Trust, International Journal of Bank Marketing, 26(7) (2008) 483-504.

41. L. Jung-Yu, K. Chih-Wei, K. R. Ulhas, Impacts of Employee Participation and Trust on E-Business Readiness, Benefits, and Satisfaction, Information Systems E-Business Management. 11 (2013) 265-285.

42. A. Benlian, \& T. Hess, The Signaling Role of IT Features in Influencing Trust and Participation in Online Communities, International journal of Electronic Commerce, 15(4) (2011) 7-56.

43. S. Petter, W. DeLone, E. R. McLean, Information Systems Success: The Quest for the Independent Variables, Journal of Management Information Systems, 29(4) (2013) 7-61.

44. C. Jayawardhena, \& P. Foley, Changes in Banking Sector - The Case of Internet Banking in UK, Journal of Internet Research: Networking and Policy, 10(2000) 19-30.

45. R. A. Spreng, S. B. MacKenzie, \& R. W. Olshavsky, A Reexamination of the Determinants of Customer Satisfaction, Journal of Marketing, 60 (1996) 15-32.

46. J. J. Cronin, M. K. Brady, \& G. T. M. Hult, Assessing the Effects of Quality, Value, and Customer Satisfaction on Consumer Behavioral Intentions in Service Environments, Journal of Retailing. 76 (2000) 193-218.

47. P. K. Hellier, G. M. Geursen, R. A. Carr, \& J. A. Rickard, Customer Repurchase Intention: A General Structural Equation Model, European Journal of Marketing, 37 (2003) 1762-1800.
48. S. Durvasula, S. Lysonski, S. C. Mehta, \& B. P Tang, Forging Relationships with Services: The Antecedents that Have An Impact on Behavioural Outcomes in the Life Insurance Industry, Journal of Financial Services Marketing, 8 (2004) 314-326.

49. B. R. Lewis, \& M. Soureli, The Antecedents of Consumer Loyalty in Retail Banking, Journal of Consumer Behaviour, 5 (2006) 15-31.

50. J. D. McKeen, T. Guimares, \& J. C. Wetherbe, The Relationship between User Participation and User Satisfaction: An Investigation of Four Contingency Factors, MIS quarterly, 18(4) (1994) 427-451.

51. B. J. Corbitt, T. Thanasankit, \& H. Yi, Trust and ECommerce: A Study of Consumer Perceptions, Electronic Commerce Research and Applications, 2 (2003) 203-215.

52. Y. Noda, Trust in Administration and Citizen's Intent to Participate, Government Auditing Review, 16 (2009) 4969.

53. M. Bosnjak, G. Metzger, \& L. Graf, Understanding the Willingness to Participate in Mobile Surveys: Exploring the Role of Utilitarian, Affective, Hedonic, Social, SelfExpressive, and Trust-Related Factors, Social Science Computer Review, 28(3) (2010) 350-370.

54. L. F. Sugianto, \& D. R. Tojib, D. R, Modeling User Satisfaction with An Employee Portal, International Journal of Business and Information, 1(2) (2006) 239-255.

55. I. Ghozali, Structural Equation Modelling Metode Alternatif dengan Partial Least Square (PLS), (Semarang, 2006).

56. D. R. Cooper, \& P. S. Schindler, Business Research Methods. $10^{\text {ed }}$. Inc, (New York: The McGraw-Hill Companies, 2008).

57. W.W. Chin, \& P. R. Newsted, Structural Equation Modeling with Small Sample Using Partial Least Square. In Rick Hoyle (Ed), Statistical strategies for small sample research, Thousands oaks (CA: Sage Publications: 307, 1999).

58. G. L. Urban, F. Sultan, \& W. J. Qualls, Placing Trust at the Center of Your Internet Strategy, Sloan Management Review, 42(1) (2000) 39-48.

59. S. L. Jarvenpaa, \& D. S. Staples, Toward Contextualized Theories of Trust: The Role of Trust in Global Virtual Teams, Information systems research, 15 (2004) 250-264.

60. S. Rotchanakitumnuai, \& M. Speece, Modeling Electronic Service Acceptance of An E-Securities Trading System, Industrial Management and Data Systems, 109(8) (2009) 1069-1084.

61. P. G. Patterson, \& R. A. Spreng, Modelling the Relationship between Perceived Value, Satisfaction, and Repurchase Intentions in A-Business-Business, Services Context: An Empirical Examination, International Journal of Service Industry Management, 8 (1997) 414-434.

62. Y. S. Wang, Asseesing E-Commerce Systems Success: A Respecification and Validation of the DeLone and McLean Model of IS Success, Journal of Information Systems, 18 (2008) 529-557.

63. T. Koivumaki, A. Ristola, \& M. Kesti, The Effects of Information Quality of Mobile Information Services on User Satisfaction and Service Acceptance - Empirical Evidence from Finland, Behaviour \& Information Technology, 27(5) (2008) 375-385. 
64. J. E. Bailey, \& S. W. Pearson, Development of A Tool for Measurement and Analyzing Computer User Satisfaction, Management Science. 29(5) (1983) 530-545.

65. W. J. Doll, \& G. Torkzadeh, The Measurement of EndUser Computing Satisfaction, MIS Quarterly, 12(2) (1988) 259-275.

66. W. H. DeLone, \& E. R. McLean, The DeLone and McLean Model of Information Systems Success: A TenYear Update, Journal of Management Information Systems, 19(4) (2003) 9-30.

67. W. H. DeLone, \& E. R. McLean, Measuring E-Commerce Success: Applying the DeLone \& McLean Information Systems Success Model, International Journal of Electronic Commerce, 9 (2004) 31-47.

68. H. F. Lin, The Impact of Website Quality Dimensions on Customer Satisfaction in the B2C E-Commerce Context". Total Quality Management, 18(4) (2007) 363-378.

69. S. Xiao, \& I. Benbasat, The Formation of Trust and Distrust in Recommendation Agents in Repeated Interactions: A Process-Tracing Analysis, Proceedings of the 5th International Conference on Electronic Commerce (Pittsburgh, PA: 2003), pp. 287-293.

70. P. Ratnasingham, \& K. Kumar, Trading Partner Trust in Electronic Commerce Participation, Proceedings of Tenth Americas Conference on Information Systems, 2004, 544552. 